\title{
Suppression of natural killer cell activity in harbour seals (Phoca vitulina) fed Baltic Sea herring
}

\author{
P.S. Ross ${ }^{\mathrm{a}, \mathrm{b}}$, R.L. De Swart ${ }^{\mathrm{a}, \mathrm{d}}$, H.H. Timmerman ${ }^{\mathrm{b}}$, P.J.H. Reijnders ${ }^{\mathrm{c}}$, \\ J.G. Vos ${ }^{\mathrm{b}}$, H. Van Loveren ${ }^{\mathrm{b}}$, A.D.M.E. Osterhaus ${ }^{\mathrm{a}, \mathrm{b}, \mathrm{d}, *}$ \\ ${ }^{a}$ Seal Rehabilitation and Research Centre, Hoofdstraat 94a, 9968.1G Pieterburen, The Netherlands \\ ${ }^{b}$ National Institute of Public Health and Environmental Protection, 3720 BA Bilthoven, The Netherlands \\ ${ }^{\mathrm{C} D L O}$-Institute for Forestry and Nature Research, P.O. Box 167,1790 AD Den Burg, The Netherlands \\ 'Erasmus Iniversity, PO. Box 1738, 3000 DR Rotterdam. The Netherlands
}

Received 17 March 1995; revised 23 May 1995; accepted 1 June 1995

\begin{abstract}
Mass mortalities among marine mammal populations in recent years have raised questions about a possible contributory role of contaminants accumulated through the marine food chain. While viruses were shown to be the primary cause of the outbreaks, an immunotoxic action by organochlorine chemicals in affected animals could not be ruled out. We carried out a $2 \frac{1}{2}$-year immunotoxicological experiment in which two groups of 11 harbour seals each were fed herring from either the relatively contaminated Baltic Sea or the relatively uncontaminated Atlantic Ocean. Seals in the Baltic Sea group accumulated 3-4 times higher levels of $A h$ receptor-mediated 2,3,7,8-TCDD Toxic Equivalents in blubber than did their Atlantic counterparts following 2 years on the respective diets. Blood was sampled a total of 17 times during the course of the experiment for immunological evaluation, during which time the natural cytotoxic activity of peripheral blood mononuclear cells isolated from seals fed Baltic Sea herring declined to a level approximately $25 \%$ lower than that observed in seals fed Allantic herring $(P<0.01)$. Natural killer (NK) cell activity has not been previously described for a marine mammal species. We characterized the natural cytotoxic activity of harbour seal peripheral blood mononuclear cells (PBMC), and found this to be interleukin-2 (IL-2) responsive, sensitive to antibody anti-asialo GM1, and it was higher against a virus-infected target cell, like NK cells described for other mammals. As NK cells are leukocytes which play an important role in the first line of defence against viruses, the observed impairment of NK cell activity in the seals feeding on the Baltic Sea herring suggests that exposure to contaminants may have an adverse effect on the defence against virus infections in seals inhabiting polluted waters in Europe. This may therefore have affected the severity of the infections, the survival rates and the spread of infections during recent epizootics.
\end{abstract}

*Corresponding author. Tel. (+31-10) 408-8066; Fax (+31-10) 436-5145. 
Keywords: Morbillivirus; Organochlorines; Contaminants; Immunosuppression; Natural killer cells; Phoca vitulina (Harbour seal); Season

\section{Introduction}

Morbillivirus-induced mass mortalities among marine mammal populations in recent years have led to extensive speculation about the possible contributing role of organochorine pollutants. In 1988, approximately 20000 harbour seals (Phoca vituli$n a$ ) died when a newly identified morbillivirus spread rapidly through the populations inhabiting the coasts of northwestern Europe (Osterhaus et al., 1988; Dietz et al., 1989; Visser et al., 1993). Despite the isolation and characterization of the responsible virus, called phocine distemper virus or PDV, pollutants could neither be implicated nor ruled out as contributing factors. Additional mass mortalities among bottlenose dolphins (Tursiops truncatus) in the Gulf of Mexico in 1987-88 and striped dolphins (Stenella coeruleoalba) in the Mediterranean Sea in 1990-91 were also induced by morbilliviruses (Van Bressem et al., 1991; Lipscomb et al., 1994). The high trophic status of many marine mammal species predisposes these animals to accumulating high concentrations of lipophilic organochlorines, including polychlorinated biphenyls (PCBs), DDT and, to a lesser extent, polychlorinated dibenzo- $p$-dioxins (PCDDs) and polychlorinated dibenzofurans (PCDFs) (Tanabe et al., 1987; Skaare et al., 1990; Simmonds et al., 1993).

Environmentally-occurring levels of organochlorines have becn correlated with biological effects in seals. Harbour seals fed contaminated fish from the Dutch Wadden Sea in an earlier experiment had significantly lower reproductive success (Reijnders, 1986) and vitamin A and thyroid hormone levels (Brouwer et al., 1989). Organochlorine chemicals have been linked to skeletal lesions among grey (Bergman et al., 1992) and harbour seals (Mortensen et al., 1992) in the Baltic Sea. PCBs have been correlated with pathological lesions which inhibited reproduction in ringed seals in the Baltic Sea (Helle et al., 1976). While contaminants have not been conclusively shown to have played a contributory role in virus epizootics (Hall et al., 1992; Simmonds et al., 1993; Aguilar et al., 1994), the high organochlorine chemical burdens of marine mammals in many areas makes these species potentially vulnerable to the adverse effects of pollution. Evidence from studies of laboratory animals suggests that PCBs, PCDDs, and PCDFs are potent immunosuppressants (Vos and Luster, 1989). In preliminary findings, we observed a reduction in $\mathrm{T}$ lymphocyte responses and natural killer cell activity of peripheral blood mononuclear cells (PBMC) isolated from harbour seals fed herring from the Baltic Sea as compared to controls (De Swart et al., 1994), and also reduced in vivo specific delayed-type hypersensitivity and antibody responses to the antigen ovalbumin (Ross et al., 1995).

Natural killer cells are lymphocytes which represent an important first line of defence against both virus infections and tumour cells (for reviews see Lewis and McGee, 1992; Welsh and Vargas-Cortes, 1992). They have been characterized as large granular lymphocytes in mammals, which migrate directly to peripheral lym- 
phatic organs and blood following development in the bone marrow. While NK cells have been defined by surface markers in rodents (e.g. monoclonal antibody 3.2.3 in the rat (Chambers et al., 1989)) and humans (e.g. antibodies against CD16 + CD56 + (O'Shea and Ortaldo, 1992)), much of the research on these lymphocytes has relied upon a functional definition. Routine testing for natural killer cell activity in different animal species involves tumour cell-directed cytotoxicity assays. To date, however, NK cell activity has not been characterized for a marine mammal species. Natural killer cells have been shown to lyse infected cells in different viral models, without major histocompatibility complex (MHC) restriction and independent of prior exposure to the virus. They are therefore vital in the non-specific immunological defence against certain pathogens which the animal has not previously encountered, and play a role in limiting the spread of infection while a more effective specific antibody and cellular response is mounted (Welsh and Vargas-Cortes, 1992). The latter specific responses require a minimum of $4-5$ days to begin an effective clearance of virus, and initial defence against a viral infection therefore relies upon the non-specific responses, in which the natural killer cells play a vital role.

In an attempt to determine whether contaminants at environmentally-occurring levels adversely affect immune function in harbour seals, we undertook a $2 \frac{1}{2}$-year captive feeding experiment. We extend here our previous findings of impaired Tlymphocyte responses and NK cell activity in harbour seals fed Baltic Sea herring expressed as a percent of control (De Swart et al., 1994), by describing the specific natural cytotoxic activity of peripheral blood mononuclear cells isolated from both the Atlantic and Baltic groups of seals. Since natural killer cells have not been described for harbour seals, we first undertook a series of assays to determine the feasibility of measuring natural cytotoxicity of leukocytes isolated from harbour seals, and to characterize this activity in harbour seals from comparative knowledge of NK cells in other mammals.

\section{Materials and methods}

\section{Captive seal feeding experiment}

Twenty-two recently weaned harbour seals were captured on the relatively unpolluted north-east coast of Scotland in 1990 and housed as described elsewhere (De Swart et al., 1994). Briefly, seals were fed relatively uncontaminated herring from the North Atlantic Ocean for a period of 1 year prior to the start of the feeding experiment. The seals were matched for weight and sex and subscquently divided at random between two groups of 11 . The two groups were then fed their respective diets of herring originating from either the North Atlantic Ocean or the Baltic Sea, commencing in late September 1991. A supplement of vitamins was added weekly to the seal diets to compensate for losses during storage at $-20^{\circ} \mathrm{C}$. The nutritional quality of the two diets and the similar clinical chemistry profiles and weight gain patterns of the two groups of seals suggest that, other than the differences in intakes of contaminants, the two groups of seals were comparable (De Swart et al., 1994; De Swart et al., in press). 


\section{Sampling}

Blood was drawn every 6-9 weeks from the epidural vein of the seals for tests of immune function. Heparinized Vacutainers (Becton Dickinson, New Jersey, USA), kept at room temperature prior to sampling, were used for the collection of approximately $40 \mathrm{ml}$ blood.

Blubber biopsies were taken aseptically from the 22 seals at week 104 of the experiment as described previously (Ross et al., 1995). Briefly, $200 \mathrm{mg}$ of blubber was sampled by inserting a $6 \mathrm{~mm}$ biopsy plug (Codman and Shurtleff, Randolph, USA) into a small incision in the skin on the dorsal surface of the seal, approximately $10 \mathrm{~cm}$ lateral to the spinal column. Samples were stored in glass vials at $-20^{\circ} \mathrm{C}$ until analysis.

\section{Isolation of leukocytes}

Peripheral blood mononuclear cells (PBMC) were isolated from heparinized whole blood which was diluted 1:2 with cell culture medium (RPMI 1640 (Gibco, Life Technologies, Paisley, Scotland) containing penicillin (100 IU/ml), streptomycin $(100$ $\mu \mathrm{g} / \mathrm{ml}$ ) and L-glutamine $(2 \mathrm{mM})$ ) and $10 \mathrm{IU} / \mathrm{ml}$ sodium heparin (Organon Teknika, Boxtel, The Netherlands) on a Lymphoprep (Nycomed Pharma, Oslo, Norway) 1.077 $\mathrm{g} / \mathrm{ml}$ density gradient at room temperature within $6 \mathrm{~h}$ of sampling as previously described (De Swart et al., 1993). Briefly, PBMC isolated following density gradient separation were washed in cell culture medium with the following added to respective washing steps: twice with $10 \mathrm{IU} / \mathrm{ml}$ sodium heparin; followed by $10 \mathrm{IU} / \mathrm{ml}$ sodium heparin plus $3 \%$ heat-inactivated fetal calf serum (FCS; Bockneck Laboratories, Guelph, Canada); and twice in $3 \%$ FCS only. Following overnight storage at $0^{\circ} \mathrm{C}$ in culture medium containing $20 \%$ FCS, PBMC were washed once in culture medium containing $10 \%$ FCS. The cell pellet was resuspended, counted using a haemocytometer, and adjusted to a standard concentration of $1 \times 10^{7}$ cells $/ \mathrm{ml}$ in culture medium containing $3 \%$ FCS.

\section{Natural killer cell assays}

YAC-1 tumour cells of murine origin were used as targets for cytotoxicity in routine experiments. Briefly, $1 \times 10^{6}$ YAC- 1 cells were radiolabelled with $100 \mu \mathrm{Ci}{ }^{51} \mathrm{Cr}$ in $100 \mu 1$ cell culture medium containing $10 \% \mathrm{FCS}$ for $45 \mathrm{~min}$ at $37^{\circ} \mathrm{C}$, washed five times in culture medium containing $10 \%$ FCS, and viable cells counted using Trypan blue dye exclusion. Natural killer cell assays consisted of a coincubation of $1 \times 10^{6}, 5 \times 10^{5}$, and $2.5 \times 10^{5}$ seal PBMC (effector cells) with $1 \times 10^{4}$ radiolabelled YAC- 1 target cells in a final well volume of $200 \mu \mathrm{l}$ in 96-well round-bottom plates (Costar, Cambridge, USA) for $6 \mathrm{~h}$ at $37^{\circ} \mathrm{C}$ in a humidified, $5 \% \mathrm{CO}_{2}$ atmosphere. Three effector: target cell ratios were therefore tested for each seal at each routine sampling (100:1, 50:1, and $25: 1$ ). The specific release of ${ }^{51} \mathrm{Cr}$ by YAC-1 target cells reflected the natural cytotoxic activity of the PBMC, and was calculated as: (radioactive counts in the supernatant - the spontaneous release by YAC-1)/(the maximal release by YAC-1 - the spontaneous release by YAC-1).

In a parallel series of experiments, we characterized the activity of the effector cells responsible for natural cytotoxicity in our seal experiments. For these purposes, 
PBMC from the seals fed North Atlantic herring were used, and standard 6-h cytotoxicity assays using an effector:target ratio of 100:1 were undertaken with an additional treatment during the assay:

(a) a coincubation of $100 \mathrm{IU} / \mathrm{ml}$ recombinant human Interleukin-2 (rhIL-2; EuroCetus, Amsterdam, The Netherlands);

(b) a coincubation with culture medium, a 1:20 final dilution of anti-asialo GM1 antibodies (Wako Chemicals, Neuss, Germany), or a mixture of a $1: 20$ final dilution of anti-asialo GM1 plus a 1:60 final dilution of rabbit complement (Cedarlane Laboratories, Hornby, Canada);

(c) $200 \mathrm{U} / \mathrm{ml}$ final concentration of recombinant human gamma-Interferon (rhIFN) in a coincubation during the assay, or separately in a 15-min pre-incubation and subsequent washing of effector cells immediately prior to the assay;

(d) using P815 mastocystoma, K-562 human myeloid leukemia, Nalm-6 pre-B human leukemia, and Nalm-6 infected with Influenza A virus H1N1 (PR8 strain) in a 90-min infection without FCS prior to the assay, as replacement targets for the YAC1 cells.

For the purpose of immunotoxicological monitoring of the two groups of study seals, the natural cytotoxic activity of isolated PBMC was measured against YAC-1 target cells in a 6-h assay under identical sampling and culture conditions at each blood sampling. Following two preliminary experiments prior to the start of the feeding experiment using standard 4-h cytotoxicity tests, it was decided to use 6-h tests in order to enhance the sensitivity of the system. There were no significant differences in the natural cytotoxic activity of PBMC between the two groups in the two experiments undertaken prior to the start of the feeding experiment (Atlantic $17.3 \pm$ s.e. 5.8 vs. Baltic $23.9 \pm$ s.e. 5.8 ; Atlantic $19.3 \pm$ s.e. 2.7 vs. Baltic $13.8 \pm$ s.e. 4.5). During the course of the feeding experiment, blood was sampled 15 times for assay. Statistical analysis was undertaken using a split-plot ANOVA with time, sex and diet as factors. Natural cytotoxic activity was averaged for blood samples taken during the entire feeding period and these data were correlated against indicators of contaminant burden in seal blubber: total TEQ for dioxins and furans; TEQs for planar PCB congeners; and TEQs for mono- and di-ortho PCB congeners.

\section{Electron microscopy}

We assessed the extent to which platelets may have interfered with cytotoxicity assays. For this, a qualitative evaluation of PBMC samples isolated from seal blood was undertaken using standard techniques of scanning electron microscopy (i) during winter (February) and summer (July) for four animals; and (ii) using PBMC from seals with high cytotoxic activity and low cytotoxicity from four seals in the two groups. We have previously encountered problems in the density gradient isolation of seal PBMC as a consequence of platelet activation (unpublished observations), and such an evaluation was carried out in order to exclude a methodological artefact in observed cytotoxicity results. For scanning microscopy, $10 \times 10^{6}$ PBMC were washed in phosphate-buffered saline, fixed ( $4 \%$ formaldehyde (containing 10-14\% methanol) and $1 \%$ glutaraldehyde solution, buffered with $0.1 \mathrm{M}$ sodium cacodylate- $\mathrm{HCl}$ ), and mounted on $0.1 \mathrm{M}$ poly-L-lysine coated glass microscope cover slides. 
Chemical residue analysis

The intake of organochlorines was estimated at $288 \mathrm{ng} \mathrm{TEQ} / \mathrm{seal}$ per day in the Baltic Sea group, compared to $29 \mathrm{ng} \mathrm{TEQ} / \mathrm{seal}$ per day in the Atlantic group (De Swart et al., 1994).

Blubber biopsy samples were used for congener-specific analyses of planar (IUPAC numbers 77, 126 and 169) and mono- (IUPAC numbers 118, 156, and 189) and di-ortho (IUPAC number 180) PCBs. Analyses were undertaken using methods described elsewhere (Boon et al., 1987; Van der Velde et al., 1994). All 2,3,7,8-chlorine-substituted dioxin $(n=7)$ and furan $(n=10)$ congeners were measured using methods described elsewhere (Liem et al., 1990). Concentrations of these congeners were used to calculate 2,3,7,8-TCDD Toxic Equivalents (TEQs) in seal blubber using the Toxic Equivalent Factors (TEFs) described for PCBs by Ahlborg et al. (1994) and for dioxins and furans by Van Zorge et al. (1989). Individual values for all 22 seals are presented here, while means of the two groups have been presented elsewhere (Ross et al., 1995).
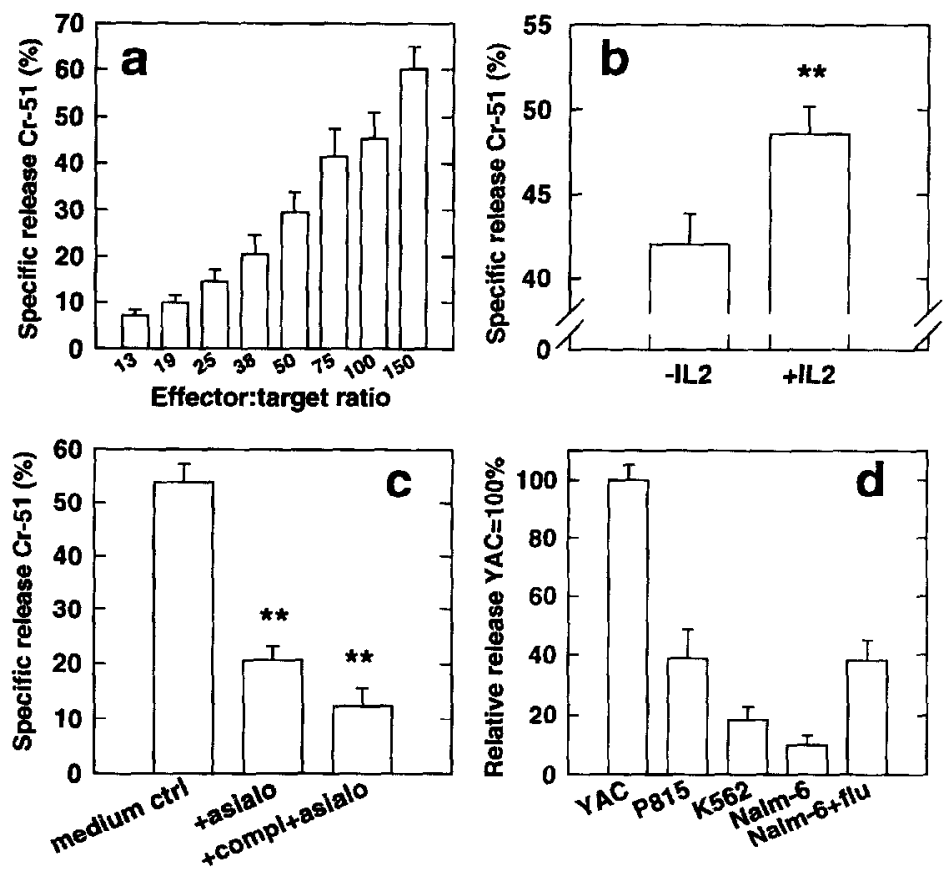

Fig. 1. Natural cytotoxicity assays were undertaken using PBMC from harbour seals: (a) using YAC-1 target cells at different effector: target cell ratios; (b) with recombinant human interleukin-2 (rhIL-2) using a 100:1 effector: target ratio; (c) with medium only, the antibody anti-asialo GM1, or a mixture of complement and anti-asialo GM1 using a 100:1 effector :target ratio; (d) using four different target cells, as compared to the standard YAC-1 tumour cell (using a corrceted YAC $=100 \%$ ) using a 100:1 cffector:target ratio. In all experiments, 6-h cytotoxicity assays were undertaken using PBMC from 11 seals of the Atlantic group and ${ }^{51} \mathrm{Cr}$-labelled target cells. Mean \pm s.e. are plotted and significance is indicated by asterisks where appropriate using paired $t$-tests $(P<0.01)$. 


\section{Results}

Natural cytotoxic activity in harbour seal PBMC

The specific ${ }^{51} \mathrm{Cr}$ release by YAC-1 target cells following coincubation with different concentrations of seal PBMC showed characteristic patterns of natural cytotoxicity, as higher effector: target ratios resulted in a high specific release as compared to lower effector:target ratios (Fig. 1a). The specific release observed during preliminary experiments using YAC-1 cells was relatively low, but this was resolved by increasing assay incubation time from 4 to $6 \mathrm{~h}$. The sensitivity of the YAC-1 cells to lysis made this cell line a suitable target for use in the routine assays during the course of the feeding study.

The natural cytotoxic activity of seal PBMC was significantly enhanced when the assay was undertaken in a coincubation with rhIL-2 (paired $t$-test, $P<0.01$; Fig. 1 b). Conversely, the antibody anti-asialo significantly reduced the natural cytotoxic activity of seal PBMC, and complement plus anti-asialo almost completely eliminated cytotoxic activity (paired $t$-test, $P<0.01$; Fig. 1c). Recombinant human Interferon had no effect on cytotoxic activity, whether assayed in a coincubation during the assay, or following a pre-incubation and subsequent washing of effector cells (results not shown). While YAC-1 cells proved to be highly sensitive to the cytotoxic activity of seal PBMC, other cell lines were somewhat less so (Fig. 1d). P815 cells exhibited lower specific release, though there was considerable inter-animal variability. K562 cells were relatively insensitive to lysis by seal PBMC. While Nalm-6 cells were also insensitive as target cells, the same cells infected with influenza virus proved to be relatively sensitive targets.

\section{Contaminant burdens in seal blubber}

Following 2 years on the different diets, the mean toxicological burden of total TEQs in blubber differed between the two seal groups by a factor of approximately

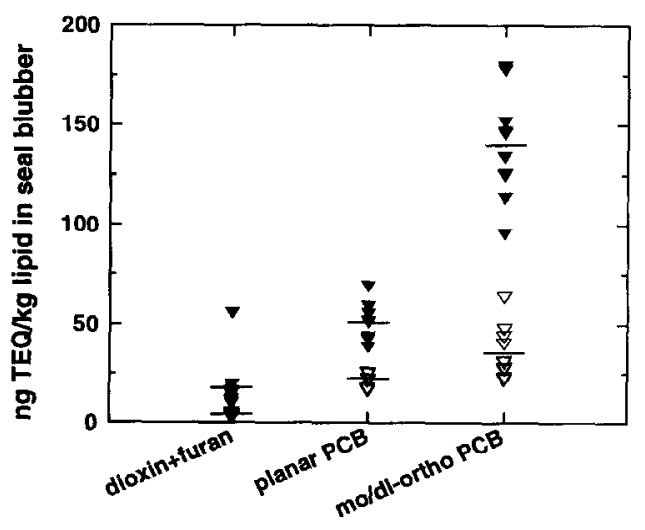

Fig. 2. Conlaminant burdens in blubber sampled from individual seals fed Atlantic herring (open symbols) or Baltic herring (closed symbols) following 2 years on the respective diets. Contaminants were grouped here as (i) dioxin (PCDD) and furan (PCDF) TEQs; (ii) planar PCB TEQs; and (iii) mono- and di-ortho PCB TEQs. Means of the two groups are indicated by a solid dash. 


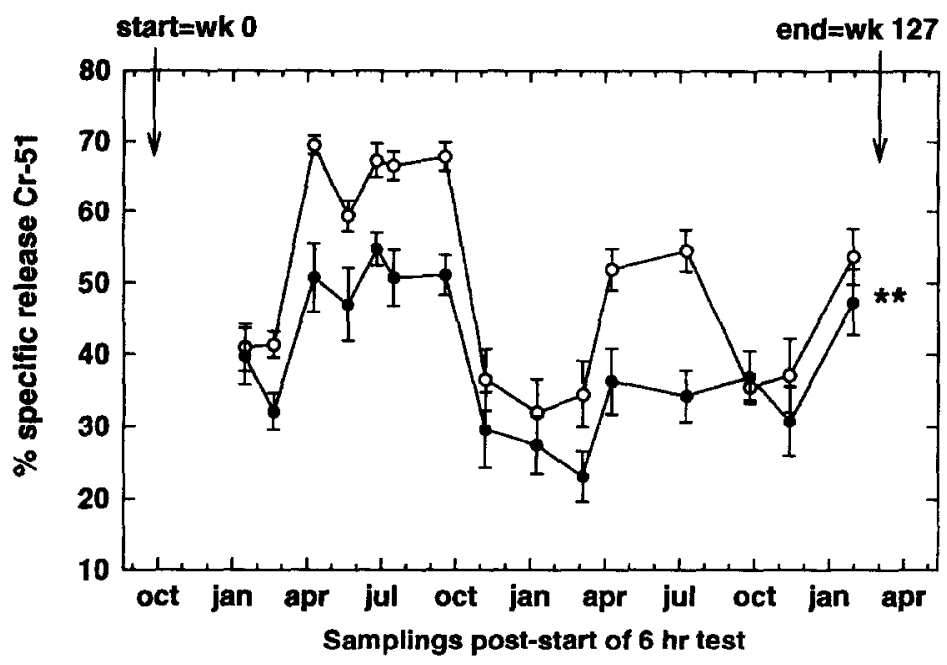

Fig. 3. Natural cytotoxic activity of PBMC isolated from harbour seals fed herring from either the relatively contaminated Baltic Sea (solid symbols) or the relatively uncontaminated Atlantic Ocean (open symbols). Activity was measured as the specific release of ${ }^{51} \mathrm{Cr}$ from YAC-1 target cells in a 6-h coincubation with seal PBMC at an effector: target ratio of 100:1. Data points represent the mean \pm s.e. of 11 seals. Differences between the two groups during the course of the feeding experiment were significant as measured by a split-plot analysis of variance $(P<0.01)$.

3.4, with mono- and di-ortho PCB congeners accounting for the majority of the total TEQ composition (Fig. 2). Mean natural cytotoxic activity of the PBMC of all seals during the entire feeding study was significantly correlated with the contaminant burden of seal blubber, whether measured against TEQ PCDD and PCDF $(r=-0.32)$, TEQ planar PCBs $(r=-0.49)$, TEQ mono and di-ortho PCBs $(r=-0.56)$, total TEQ $(r=-0.55)$, or concentration PCB $(r=-0.68)$.

\section{Monitoring of natural cytotoxicity of PBMC during the feeding experiment}

There was considerable temporal variation in the cytotoxic activity of the seal PBMC, but seals fed the Baltic Sea herring had consistently and significantly reduced natural cytotoxic cell activity as compared to the seals fed the Atlantic Ocean herring over time, a trend which began within 4 months of the start of the feeding experiment (Fig. 3). The effect of pollution (diet group) was significant at the $P<0.01$ level (split-plot ANOVA). Natural cytotoxic cell activity was identical in both groups in the first 6-h assay, carried out 16 weeks following the start of the feeding experiment (Atlantic $26.0 \pm$ s.e. 3.3 vs. Baltic $25.1 \pm$ s.e.; see Fig. 3), after which it declined in the Baltic group. There were no sex-related differences. An apparent seasonal pattern emerged in the responses of the seals in the two groups, with natural cytotoxic cell activity in winter being approximately half of that observed during the summer months for both groups of seals. There were no discernible differences in platelet presence or activation in the electron microscope preparations between summer and winter, or between low and high cytotoxic responders. 


\section{Discussion}

The characterization of the effector cells responsible for target cell-directed cytotoxicity from our harbour seals suggests that they have similar functional properties to natural killer cells described in other mammals, including mice (Colmenares and Lopez, 1986), rats (De Jong et al., 1980), chickens (Keller et al., 1992), dogs (Knapp et al., 1993), cattle (Campos et al., 1992), pigs (Richerson and Misfeldt, 1989), horses (Chong et al., 1992), and humans (Timonen et al., 1981; Herberman et al., 1986). The classic pattern of natural killer cell-induced cytotoxicity, as observed at different effector:target ratios (Lewis and McGee, 1992), was apparent when PBMC from our seals were coincubated with radiolabelled YAC-1 tumour cells (i.e. higher numbers of effector cells, higher release of ${ }^{51} \mathrm{Cr}$ by radiolabelled YAC-1 target cells). We have shown the effector cells in seals which lysed YAC-1 target cells to be IL-2 responsive, a trait shared by NK cells in other mammals studied (Henney et al., 1981). The antibody anti-asialo GM1, when combined with complement, virtually eliminated cytotoxic activity from seal PBMC in a coincubation. Anti-asialo GMl is an antibody which binds to the cell surface glycolipid GM1 of NK cells and some macrophages in several mammalian species, including mice (Kasai et al., 1981), and has been shown to suppress or abolish NK cell activity when administered in vivo (Kasai et al., 1981) or in vitro (Ikeda et al., 1991). Human gamma-Interferon did not enhance or block natural cytotoxicity, indicating a non-responsiveness of seal leukocytes, which may be expected for this this non-autologous cytokine. Preincubation with autologous interferon leads to enhanced NK cell cytotoxicity in mice (Djeu et al., 1979), but can also protect virus-infected target cells against lysis (Bukowski and Welsh, 1985). Since NK cells in mammals comprise a population of leukocytes which are generally defined by their functional properties, our observations support the concept that the assay system indeed detects the activity of NK cells in harbour seals.

The lower natural killer cell activity in seals of the Baltic group suggests that contaminants accumulated in the marine food chain are immunotoxic, and impair such activity by a mechanism which remains to be elucidated. Suppression of natural killer cell activity has been demonstrated in laboratory animals exposed to $3.9 \mu \mathrm{g} / \mathrm{g}$ diet methyl mercury (Ilbäck et al., 1991); to $20 \mathrm{mg} / \mathrm{kg}$ diet bis(tri- $n$-butyltin)oxide (TBTO) or $150 \mathrm{mg} / \mathrm{kg}$ hexachlorobenzene (HCB) (Van Loveren et al., 1990); and to $50 \mathrm{mg}$ Aroclor 1254 (PCB)/kg in feed over a 10-week period (Talcott et al., 1985). Exposure to 2,3,7,8-TCDD has led to both an increase (Funseth and Ilbäck, 1992) and to no change (Yang et al., 1994) in baseline natural killer cell activity in rodents, though in the former study, an Influenza virus-associated increase in NK cell activity was suppressed in exposed compared to control animals. Host resistance to pathogens can be reduced by organochlorine chemicals as evidenced by higher virus titers and increased mortality following pathogenic challenge (Loose et al., 1978; House et al., 1990; for review see Vos et al., 1991).

The seasonal variation in NK cell activity in our harbour seals may be of interest in the continuing debate surrounding the complex immune system-pollution-disease matrix in the PDV epizootic. Seasonal cycles in immune responses including antibody production (Maestroni et al., 1987) and lymphocyte proliferation responses to mito- 
gens (Boctor et al., 1989) have been demonstrated, though to our knowledge, this has not been previously established for NK cell activity. Seasonality in immune function is hypothesized to be mediated via photoperiod length-induced changes in the release of melatonin by the pineal gland (Maestroni et al., 1987). Since no discernible differences were found in platelet presence or state of activation in PBMC samples from winter and summer or from seals with low and high cytotoxic activity, as examined using electron microscopy, an artefact introduced by platelets interfering with NKtarget binding was ruled out as a possible factor in the seasonal patterns in cytotoxicity and in differences between the two groups of seals. Taken together, it may be speculated that the influence of both contaminants and season may represent significant factors affecting the outcome of NK cell-mediated virus infections in marine mammals.

Natural killer cell deficiencies have led to increased susceptibility to virus infections in different situations. A human patient suffering from recurring and life-threatening virus infections including varicella, hepatitis, cytomegalovirus, and herpes simplex, lacked functional NK cells, but all other immune parameters examined were normal (Biron et al., 1989). NK-deficient young mice (Boos et al., 1971) and beige mice (Shellam et al., 1981) are less resistant to mouse cytomegalovirus MCMV. SteinStreilen and Guffee (1986) showed that the in vivo administration of anti-asialo to mice and hamsters resulted in diminished survival rates following challenge with influenza virus. Welsh et al. (1991) found that mice administered anti-asialo GM-1 had higher mortality rates and virus titers following MCMV infection as compared to control mice. Our observation that influenza virus-infected Nalm-6 cells were more effectively lysed than their control counterparts supports the notion that NK cells in harbour seals play a role in early responses to viral infections, as has been shown in other mammals (Casali and Trinchieri, 1984).

While it is difficult to assess the in vivo significance of the observed decline in NK cell activity in the seals fed the Baltic Sea herring in our study, it is clear that diminished NK cell activity can have serious clinical repercussions. In the case of the PDV-epizootic among harbour seals that started in 1988, a virus was introduced to an immunologically naive population. Under normal circumstances, non-specific immunological defences, particularly NK cells, would respond in an attempt to eliminate or slow the spread of the virus in the first $2-4$ days of infection. Specific T- and B-cell responses would then follow in order to clear the virus 5-8 days following infection and maintain protection against future encounters with the same virus by immunological memory. If both a first line of defence against virus infections (NK cells), as well as specific T-cell responses, were less functional as a consequence of contaminant-induced immunosuppression, pollution could well have contributed to the severity and extent of the outbreak. Our study seals were not perinatally exposed to the high contaminant diet, and accumulated a mean contaminant burden during the course of the feeding study which was lower than that observed in many seal populations of Europe. This suggests that free-ranging populations of seals in Europe may be at a higher risk to the effects of contaminant-induced immunosuppression than our captive seals. The multitude of factors that affect the outcome of a virus epizootic (e.g. population density, social behaviour, immunological memory) make it impossible to 
directly relate contaminant levels to mortality rates in an event such as the 1988 PDV outbreak. As such, contaminants may be expected to play a role in, but not directly govern, the course and outcome of a virus epizootic.

It is impossible to identify any particular contaminant in the Baltic Sea herring which led to the suppression of NK cell activity, owing to the presence of hundreds of different PCB, PCDD and PCDF congeners, as well as numerous other potentially immunotoxic chemicals. The correlation analysis suggests only an inverse relationship between NK cell activity and environmental 'contaminants', since the Baltic Sea herring had elevated levels of all compounds measured. However, the available evidence suggests that the Ah-receptor mediated PCBs, PCDDs and PCDFs have the most immunotoxic potential (Vos and Luster, 1989) and may, through an additive effect, contribute to a complex immunotoxic mixture of contaminants in the Baltic Sea food chain. Since mono- and di-ortho PCBs largely contributed to the TEQ profile in the seal blubber, we have speculated that they may be, to a large extent, responsible for the observed impairment in T-lymphocyte mediated specific immune responses (Ross et al., 1995), and may also affect the NK cell activity reported here. The more rapid appearance of an impairment in NK cell activity (4 months) than T-lymphocyte responses ( 1 year) may be due to the ontogeny of these two leukocyte subpopulations. While both NK cells and T-lymphocytes or their precursors originate in the bone marrow, NK cells are fully functional soon after they enter the bloodstream, whereas T-lymphocytes must first migrate to the thymus and mature there. In addition, NK cells have a rapid turnover (Trinchieri, 1989) compared to T-lymphocytes (Michie et al., 1992), and this may result in an earlier systemic manifestation of an immunotoxic mechanism taking place in the bone marrow and/or thymus. Since both cell types play vital roles in fighting virus infections, several marine mammal species may be under increased threat of infection by pathogens in industrialized coastal areas.

\section{Acknowledgements}

The authors gratefully acknowledge the assistance of the many individuals, without whom this study would not have been possible: all the staff of the Seal Rehabilitation and Research Centre, Siem Heisterkamp, Djien Liem, Trudy Riool, Harry Ross, Elze Ruiter, Koos Teppema and Paul Thompson. Research was supported in part by a Natural Sciences and Engineering Research Council of Canada award to PSR and a Nederlandse Aardolie Maatschappij grant to RLD.

\section{References}

Aguilar, A. and A. Borrell (1994) Abnormally high polychlorinated biphenyl levels in striped dolphins (Stenella coeruleoalba) affected by the 1990-92 Mediterranean epizootic. Sci. Total Environ. 154, 237247.

Ahlborg, U.G., G.C. Becking, L.S. Birnbaum, A. Brouwer, H.J.G.M. Derks, M. Feeley, G. Golor, A. 
Hanberg, J.C. Larsen, A.K.D. Liem, S.H. Safe, C. Schlatter, F. Waern, M. Younes and E. Yrjänheikki (1994) Toxic equivalency factors for dioxin-like PCBs. Chemosphere 28, 1049-1067.

Bergman, A., M. Olsson and S. Reiland (1992) Skull-bone lesions in the Baltic grey seal (Halichoerus grypus). Ambio 21, 517-519.

Biron, C.A., K.S. Byron and J.L. Sullivan (1989) Severe herpesvirus infections in an adult without natural killer cells. New Engl. J. Med. 320, $1731-1735$.

Boctor, F.N., R.A. Charmy and E.L. Cooper (1989) Seasonal differences in the rhythmicity of human male and female lymphocyte blastogenic responses. Immunol. Invest. 18, 775-784.

Boon, J.P., P.I.H. Reijnders, J. Dols, P. Wensfort and M.T.I. Hillebrand (1987) The kinetics of individual polychlorinated biphenyl congeners in female harbour seals (Phoca vitulina), with evidence for structurerelated metabolism. Aquat. Toxicol. 10, 307-324.

Boos, J. and E.F. Wheelock (1971) Correlation of survival from MCMV infection with spleen cell responsiveness to concanavilin A. Proc. Soc. Exp. Biol. Med. 149, 443-446.

Brouwer, A., P.J.H. Reijnders and J.H. Koeman (1989) Polychlorinated biphenyl (PCB)-contaminated fish induces vitamin A and thyroid hormone deficiency in the common seal (Phoca vitulina). Aquat. Toxicol. $15,99-106$.

Bukowski, J.F. and R.M. Welsh (1985) Inability of interferon to protect virus-infected cells against lysis by natural killer (NK) cells correlates with NK cell-mediated antiviral effects in vivo. J. Immunol. 135, 3537-3541.

Campos, M., C.R. Rossi, H.B. Ohmann, T. Beskorwayne, N. Rapin and L.A. Babiuk (1992) Characterization and activation requirements of bovine lymphocytes acquiring cytotoxic activity after interleukin-2 treatment. Vet. Immunol. Immunopathol. 32, 205-223.

Casali, P. and G. Trinchieri (1984) Natural killer cells in viral infection. In: Concepts in Viral Pathogenesis, edited by A.L. Notkins and M.B.A. Oldstone. Springer-Verlag, New York, pp. 11-19.

Chambers, W.H., N.L. Vujanovic, A.B. DeLeo, M.W. Olszowy, R.B. Herberman and J.C. Hiserodt (1989) Monoclonal antibody to a triggering structure expressed on rat natural killer cells and adherent lymphokine-activated killer cells. J. Exp. Med. 169, 1373-1389.

Chong, Y.C., W.P.H. Duffus and D. Hannant (1992) Natural killer cells in normal horses and specificpathogen-free foals infected with equine herpesvirus. Vet. Immunol. Immunopathol. 33, 103-113.

Colmenares, C. and C. Lopez (1986) Enhanced lysis of herpes simplex virus type l-infected mouse cell lines by NC and NK effectors. J. Immunol. 136, 3473-3480.

De Jong, W.H., P.A. Steerenberg, P.S. Ursem, A.D.M.E. Osterhaus, J.G. Vos and E.J. Ruitenberg (1980) The athymic nude rat: III. Natural cell-mediated cytotoxicity. Clin. Immunol. Immunopathol. 17, 163172.

De Swart, R.L., R.M.G. Kluten, C.J. Huizing, L.J. Vedder, P.J.H. Reijnders, I.K.G. Visser, F.G.C.M. UytdeHaag and A.D.M.E. Osterhaus (1993) Mitogen and antigen induced T and B cell responses of peripheral blood mononuclear cells from the harbour seal (Phoca vitulina). Vet. Immunol. Immunopathol. $37,217-230$.

De Swart, R.L., P.S. Ross, L.J. Vedder, H.H. Timmerman, S.H. Heisterkamp, H. van Loveren, J.G. Vos, P.J.H. Reijnders and A.D.M.E. Osterhaus (1994) Impairment of immune function in harbour seals (Phoca vitulina) feeding on fish from polluted waters. Ambio 23, 155159.

De Swart, R.L., P.S. Ross, L.J. Vedder, P.J.H. Reijnders, P.G.H. Mulder and A.D.M.E. Osterhaus (in press) Haematology and clinical chemistry values for harbour seals (Phoca vitulina) fed environmentally contaminated herring remain within normal ranges. Can. J. Zool.

Dietz, R., M.-P. Heide-Jorgensen and T. Härkönen (1989) Mass deaths of harbor seals (Phoca vitulina) in Europe. Ambio 18, 258-264.

Djeu, J.Y., J.A. Heinbaugh, H.T. Holden and R.B. Herberman (1979) Augmentation of mouse natural killer cell activity by interferon and interferon inducers. J. Immunol. 122, 175-181.

Funseth, E. and N.-G. Ilbäck (1992) Effects of 2,3,7,8-tetrachlorodibenzo-p-dioxin on blood and spleen natural killer (NK) cell activity in the mouse. Toxicol. Lett. 60, 247-256.

Hall, A.J., R.J. Law, D.E. Wells, J. Harwood, H.M. Ross, S. Kennedy, C.R. Allchin, L.A. Campbell and P.P. Pomeroy (1992) Organochlorine levels in common seals (Phoca vitulina) which were victims and survivors of the 1988 phocine distemper epizootic. Sci. Total Environ. 115, 145-162. 
Helle, E., M. Olsson and S. Jensen (1976) PCB levels correlated with pathological changes in seal uteri. Ambio 5, 261-263.

Henney, C.S., K. Kuribayashi, D.E. Kern and S. Gillis (1981) Interleukin-2 augments natural killer cell activity. Nature 291, 335-338.

Herberman, R.B., C.W. Reynolds and J.R. Ortaldo (1986) Mechanism of cytotoxicity by natural killer (NK) cells. Annu. Rev. Immunol. 4, 651-680.

House, R.V., L.D. Lauer, M.J. Murray, P.T. Thomas, J.P. Ehrlich, G.R. Burleson and J.H. Dean (1990) Examination of immune parameters and host resistance mechanisms in $\mathrm{B} 6 \mathrm{C} 3 \mathrm{~F} 1$ mice following adult exposure to 2,3,7,8-tetrachlorodibenzo-p-dioxin. J. Toxicol. Environ. Health 31, 203-215.

Ikeda, S., T. Tominaga and C. Nishimura (1991) Thy $1+$ asialo GM1 + dendritic epidermal cells in skin defense mechanisms of vaccinia virus-infected mice. Arch. Virol. 117, 207-218.

Ilbäck, N.-G., J, Sundberg and A. Oskarsson (1991) Methyl mercury exposure via placenta and milk impairs natural killer (NK) cell function in newborn rats. Toxicol. Lett. 58, 149-158.

Kasai, M., T. Yoneda, S. Habu, Y. Maruyama, K. Okumura and T. Tokunaga (1981) In vivo effect of anti-asialo GMI antibody on natural killer activity. Nature 291, 334-335.

Keller, L.H., H.S. Lillehoj and J.M. Solnosky (1992) JMV-1 stimulation of avian natural killer cell activity. Avian Pathol. 21, 239-250.

Knapp, D.W., R.R. Leibnitz, D.B. DeNicola, J.J. Turek, R. Teclaw, L. Shaffer and T.C.K. Chan (1993) Measurement of NK activity in effector cells purified from canine peripheral lymphocytes. Vet. Immunol. Immunopathol. 35, 239-251.

Lewis, C.E. and J.O'D. McGee (1992) Natural killer cells in tumour biology. In: The Natural Killer Cell, edited by C.E. Lewis and J.O'D. McGee. IRL Press, Oxford, pp. 175-203.

Liem, A.K.D., A.P.J.M. De Jong, J.A. Marsman, A.C. Den Boer, G.S. Groenemeyer, R.S. Den Hartog, G.A.L. De Korte, R. Hoogerbrugge, P.R. Kootstra and H.A. Van 't Klooster (1990) A rapid clean-up procedure for the analysis of polychlorinated dibenzo-p-dioxins and dibenzofurans in milk samples. Chemosphere 20, 843-850.

Lipscomb, T.P., F.Y. Schulman, D. Moffett and S. Kennedy (1994) Morbilliviral disease in Atlantic bottlenose dolphins (Tursiops truncatus) from the 1987-1988 epizootic. J. Wildlife Dis. 30, 567-571.

Loose, L.D., J.B. Silkworth, K.A. Pittman, K.-F. Benitz and W. Mueller (1978) Impaired host resistance to endotoxin and malaria in polychlorinated biphenyl- and hexachlorobenzene-treated mice. Infect. Immun. 20, 30-35.

Maestroni, G.J.M., A. Conti and W. Pierpaoli (1987) Role of the pineal gland in immunity: II. Melatonin enhances the antibody response via an opiatergic mechanism. Clin. Exp. Immunol. 68, 384-391.

Michie, C.A., A. McLean, C. Alcock and P.C.L. Beverley (1992) Lifespan of human lymphocyte subsets defined by CD 45 isoforms. Nature 360, 264-265.

Mortensen, P., A. Bergman, A. Bignert, H.-J. Hansen, T. Härkönen and M. Olsson (1992) Prevalence of skull lesions in harbor seals (Phoca vitulina) in Swedish and Danish museum collections: 1835-1988. Ambio 21, 520-524.

O'Shea, J. and J.R. Ortaldo (1992) The biology of natural killer cells: insight into the molecular basis of function. In: The Natural Killer Cell, edited by C.E. Lewis and J.O'D. McGee. IRL Press, Oxford, pp. $1-40$.

Osterhaus, A.D.M.E., J. Groen, P. de Vries, F.G.C.M. Uytdehaag, B. Klingeborn and R. Zarnke (1988) Canine distemper virus in seals. Nature 335, 403-404.

Reijnders, P.J.H. (1986) Reproductive failure in common seals feeding on fish from polluted coastal waters. Nature $324,456-457$.

Richerson, J.T. and M.L. Misfeldt (1989) Host environment as a modulating factor of swine natural killer cell activity. Vet. Immunol. Immunopathol. 23, 309-319.

Ross, P.S., R.L. De Swart, P.J.H. Reijnders, H. Van Loveren, J.G. Vos and A.D.M.E. Osterhaus (1995) Contaminant-related suppression of delayed-type hypersensitivity and antibody responses in harbor seals fed Baltic Sea herring. Environ. Health Persp. 103, 162-167.

Shellam, G.R., J.E. Allan, J.M. Papadimitriou and G.J. Bancroft (1981) Increased susceptibility to cytomegalovirus infection in beige mutant mice. Proc. Natl. Acad. Sci. USA 78, 5104-5108. 
Simmonds, M.P., P.A. Johnston and M.C. French (1993) Organochlorine and mercury contamination in United Kingdom seals. Vet. Rec. 132, 291-295.

Skaare, J.U., N. Hedlund Markussen, G. Norheim, S. Haugen and G. Holt (1990) Levels of polychorinated biphenyls, organochlorine pesticides, mercury, cadmium, copper, selenium, arsenic, and zinc in the harbour seal, Phoca vitulina, in Norwegian waters. Environ. Pollut. 66, 309-324.

Stein-Streilen, J. and J. Guffee (1986) In vivo treatment of mice and hamsters with antibodies to asialo GM1 increases morbidity and mortality to pulmonary influenza infection. J. Immunol. 4, 1435-1441.

Talcott, P.A., L.D. Koller and J.H. Exon (1985) The effect of lead and polychlorinated biphenyl exposure on rat natural killer cell cytotoxicity. Int. J. Immunopharmac. 7, 255-261.

Tanabe, S., N. Kannan, An. Subramanian, S. Watanabe and R. Tatsukawa (1987) Highly toxic coplanar PCBs: occurrence, source, persistency and toxic implications to wildlife and humans. Environ. Pollut. 47, $147-163$.

Timonen, T., J.R. Ortaldo and R.B. Herberman (1981) Characteristics of human large granular lymphocytes and relationship to natural killer cells and K cells. J. Exp. Med. 153, 569-582.

Trinchieri, G. (1989) Biology of natural killer cells. Adv. Immunol. 47, 187-376.

Van Bressem, M.F., I.K.G. Visser, M.W.G. van de Bildt, J.S. Teppema, J.A. Raga and A.D.M.E. Osterhaus (1991) Morbillivirus infection in Mediterranean striped dolphins (Stenella coeruleoalba). Vet. Rec. $129,471-472$.

Van der Velde, E.G., J.A. Marsman, A.P.J.M. De Jong, R. Hoogerbrugge and A.K.D. Liem (1994) Analysis and occurrence of toxic planar PCBs, PCDDs, and PCDFs in milk by use of carbosphere activated carbon. Chemosphere 28, 693-702.

Van Loveren, H., E.I. Krajnc, P.J.A. Rombout, F.A. Blommacrt and J.G. Vos (1990) Effects of ozone, hexachorobenzene, and bis(tri-n-butyl)oxide on natural killer activity in the rat lung. Toxicol. Appl. Pharmacol. 102, 21-33.

Van Zorge, J.A., J.H. Wijnen, R.M.C. Theelen, K. Olie and M. Van den Berg (1989) Assessment of the toxicity of mixtures of halogenated dibenzo-p-dioxins and dibenzofurans by use of toxic equivalency factors (TEFs). Chemosphere 19, 1881-1895.

Visser, I.K.G., M.-F. Van Bressem, T. Barrett and A.D.M.E. Osterhaus (1993) Morbillivirus infections in aquatic mammals. Vet. Res. 24, 169-178.

Vos, J.G. and M.I. Luster (1989) Immune alterations. In: Halogenated Biphenyls, Terphenyls, Naphthalenes, Dibenzodioxins and Related Products, edited by R.D. Kimbrough and A.A. Jensen. Elsevier Science Publishers, Amsterdam, pp. 295-322.

Vos, J.G., H. Van Loveren and H.-J. Schuurman (1991) Immunotoxicity of dioxin: immune function and host resistance in laboratory animals and humans. In: Banbury Report 35: Biological Basis for Risk Assessment of Dioxins and Related Compounds, edited by M.A. Gallo, R.J. Scheuplein and K.A. Van der Heijden. Cold Spring Harbor Laboratory Press, pp. 79-93.

Welsh, R.M. and M. Vargas-Cortes (1992) Natural killer cells in viral infection. In: The Natural Killer Cell, edited by C.E. Lewis and J.O'D. McGee. IRL Press, Oxford, pp. 107-150.

Welsh, R.M., J.O. Brubaker, M. Vargas-Cortes and C.L. O'Donnell (1991) Natural killer (NK) cell response to virus infections in mice with severe combined immunodeficiency. The stimulation of NK cells and the NK cell-dependent control of virus infections occur independently of $\mathrm{T}$ and $\mathrm{B}$ cell function. J. Exp. Med. 173, 1053-1063.

Yang, Y.G., H. Lebrec and G. Burleson (1994) Effect of 2,3,7,8-tetrachlorodibenzo-p-dioxin on pulmonary Influenza titer and natural killer (NK) activity in rats. Fund. Appl. Toxicol. 23, 125-131. 